\title{
MACROALGAL COMPOSITION AND ITS ASSOCIATION WITH LOCAL HYDRODYNAMICS IN THE LAJE DE SANTOS MARINE STATE PARK, SOUTHWESTERN ATLANTIC, SÃO PAULO, BRAZIL
}

\author{
Renato Rocha Jorge ${ }^{1 *}$, Joseph Harari ${ }^{2}$ and Mutue Toyota Fujiii \\ ${ }^{1}$ Instituto de Botânica da Universidade de São Paulo \\ (Av. Miguel Estéfano, 3687, 04301-902 São Paulo, SP, Brasil) \\ ${ }^{2}$ Instituto Oceanográfico da Universidade de São Paulo \\ (Praça do Oceanográfico, 191, 05508-120 São Paulo, SP, Brasil)
}

*Corresponding author: marenato@uol.com.br

\begin{abstract}
A B S T R A C T
The Laje de Santos Marine State Park (LSMSP), located in southeastern Brazil, is the only marine park in São Paulo State. This conservation unit has been established as a protected area of high biological diversity. Despite its importance for the conservation of the marine biota, little is known about the park's seaweed flora. The objectives of this study were as follows: to furnish increased knowledge of the composition of the macroalgae in the Park area; to relate the area's macroalgal composition to the presence of an important water mass in the region, the South Atlantic Central Water (SACW); and to investigate the possible influence of the Port of Santos on the composition of the macroalgae of the LSMSP. This study registered 31 new records for the LSMSP, 11 for São Paulo State, four for Brazil, one for the western Atlantic and one for the South Atlantic Ocean, in addition to the possible occurrence of one new species of Osmundea (Rhodomelaceae) and one new genus belonging to Ceramiaceae. The taxonomic composition of the macroalgae had a direct correlation with the arrival of the SACW in the summer-fall season. The SACW generated a strong thermocline and increased the supply of nutrients in the water column. Hydrodynamic and dispersion modeling analyses suggested that the Port of Santos influenced the composition of the LSMSP phycoflora.
\end{abstract}

\section{RESUMO}

O Parque Estadual Marinho da Laje de Santos (PEMLS), localizado no sudeste do Brasil, é o único parque marinho do litoral paulista. Essa unidade de conservação foi classificada como de "alta diversidade biológica". Apesar da sua importância para a preservação da biota marinha, pouco é conhecido sobre a flora de macroalgas do Parque. Os obejtivos deste estudo foram: aumentar o conhecimento da composição de macroalgas na região do PEMLS; relacionar tal composição com a presença de uma importante massa d'água na região, a Água Central do Atlântico Sul (ACAS); e verificar uma possivel influência do Porto de Santos na composição ficológica do Parque. O presente estudo registrou 31 novas ocorrências para o Parque, 11 para o estado de São Paulo, quatro para o Brasil, uma para o Atlântico Ocidental e uma para o Atlântico Sul, além de duas prováveis novas ocorrências para a ciência: uma espécie de Osmundea (Rhodomelaceae) e um gênero pertencente e Ceramiaceae. Segundo os dados encontrados, a composição de macroalgas tem uma correlação direta com a presença da ACAS no período de verão-outono. Essa frente térmica profunda promove a formação de uma forte termoclina e aumenta o aporte de nutrientes na coluna d'água. Análises dos modelos hidrodinâmico e de dispersão sugerem que o Porto de Santos pode influenciar a composição ficológica do local.

Descriptors: Macroalgal composition, Laje de Santos, Hydrodynamics.

Descritores: Composição de macroalgas, Laje de Santos, Hidrodinâmica.

\section{INTRODUCTION}

The Laje de Santos Marine State Park (LSMSP) was created in 1993. It is the only area of its kind in São Paulo State. (The only two marine parks located in the subtropical region of the western South Atlantic are the LSMSP and another one in Rio de Janeiro State). The Park is approximately 17 miles 
from Santos city, where the largest port in Latin America is located (Fig. 1). Local tourism and fisheries (the last one allowed, only, in adjacent areas) make the Park very important to society. However, many harmful activities occur owing to the lack of surveillance in this protected area. These activities include the collection of benthic organisms by aquarists or interior decorators, recreational fishing, spear fishing and the use of other illegal fishing methods. In addition, the dumping of ballast water along the borders of the conservation unit by ships that use the Port of Santos regularly has a significant impact on this fragile local ecosystem (MMA, 2011; ABESSA et al., 2005; NEVES, 1997).

The composition of the macroalgae of the LSMSP is poorly known. The only systematic survey that describes it is Amado Filho et al. (2006). This survey covered a very small portion of the Park and involved only a few sampling times (in all, four samples at only one of the 10 points sampled by the present study). Amado Filho et al. (2006) reported some new recordings for Brazil, such as Botryocladia wynnei D.L.Ballantine, Rhodymenia delicatula P. Dangeard, Hypoglossum anomalum M.J. Wynne and D.L. Ballantine, Myriogramme prostrata (E.Y. Dawson, Neushul and Wildman) M.J. Wynne and Cladosiphon occidentalis Kylin for the South Atlantic. Later, Coto and Pupo (2009) conducted a survey of Ulvophyceaean species in São Paulo State, including samples previously collected by Amado Filho et al. (2006). Based only on these few data, in 2002 the Brazilian Ministry of the Environment classified the LSMSP, with respect to "marine plants", as an area of extreme biological importance (MMA, 2002). Because the previous surveys, as mentioned above, covered a very small portion of the Park (in view of this habitat's complexity, only a small portion of the available substrata for macroalgae was sampled) and involved few sampling times, we believe that the richness of the Park's macroalgae had been underestimated, and we thus expected to be able to increase the number of taxa known for the area and to record new occurrences by increasing both the area and the number of sampling times.

During the summer and fall in the Southern Hemisphere, the Park region is strongly influenced by a deep water mass, the South Atlantic Central Water (SACW). In this season, visually, there is a considerable increase in the number of macroalgal taxa. The presence of this water mass in the area could be an important reason for the great richness of the macroalgae because it changes some of the hydrographic properties of the water column and could favor the seasonal development of some species in the LSMSP. But beyond this, other factors certainly contribute to the great richness of the Park because, when this water mass is present, the basic hydrographic conditions in the LSMSP ( $\mathrm{pH}$, temperature, salinity and wave exposure) are similar to those that occur in other regions of the São Paulo coastal area (MIRANDA et al., 2003), also influenced by the SACW. More studies have been conducted in those regions than in the Park area, but the richness of the macroalgae reported is lower than that in LSMSP. As mentioned above, the Park is located near the Port of Santos, which receives approximately 5,600 ships per year (SECRETARIA DE PORTOS, 2011). The introduction of species from ballast water has now been well documented (BIJ DE VAATE, 2010; GRAY; MACISAAC, 2010; BAILEY et al., 2005). We hypothesized that the Port could influence the conservation unit by allowing the introduction of new macroalgal taxa from ships (in ballast water or encrusted on the hull), contributing to its richness. The coastal circulation is very complex and variable in space and time so these organisms would be transported from nearby areas into the LSMSP by marine currents. The transport of organisms by currents is known and has been described for decades BAGGERMAN, 1953; RENAUD-DEBYSER; SALVAT, 1963; BAYNE, 1964; BEUKEMA; DE VLAS, 1989; BONSDORFF, 1992). Drift is an important dispersal mechanism for both algae and the associated fauna. Dispersal distances have been studied in numerous localities over a range of spatial scales (BIBER, 2007).

A hydrodynamic study was performed using advection and diffusion particle analysis to investigate the possibility that the currents carrying species from Port (or adjacent areas) to the Park influence the macroalgal composition. The occurrence of the macroalgal taxa was analyzed in two different seasons (the austral summer/fall and winter/spring) to verify a possible relationship between the seasonal macroalgal composition and the presence/absence of SACW.

\section{Material and Methods}

\section{Study área}

The area of the Laje de Santos Marine State Park is 5,000 ha. The following features constitute its primary substrata: a large rock formation (Laje de Santos) $33 \mathrm{~m}$ high, $550 \mathrm{~m}$ long and $185 \mathrm{~m}$ wide; a pair of cliffs called "Calhaus"; and four reefs (Brilhante, Bandolim, Sul and Novo) (Fig. 1). The hard substrata available for macroalgal development extend to a depth of $40 \mathrm{~m}$ and represent an important habitat that supports a high density and diversity of marine life. This habitat is primarily occupied by macroalgae, zoanthids, hydrozoans, ascidians, octocorals and coral colonies of both Madracis decactis Lyman, 1859 and Mussismilia hispida Verrill, 1901 (NEVES, 1997; LUIZ-JUNIOR et al., 2008). Different species of 
animals and macroalgae, of a great variety of shapes and colors, are found in close association with the sandy and rocky substrata. In addition, large shoals of pelagic fish visit the Park and use it as a feeding and breeding area. These uses demonstrate the importance of the site for maintaining the region's fishing potential.

The influence of ocean currents and physical properties on the rocky complex allows visibility of up to $30 \mathrm{~m}$. This excellent visibility makes the area, with its biological diversity, one of the major diving sites in Brazil, comparable to the best in the world (NEVES, 1997).

The LSMSP is situated in a transitional zone between tropical and sub-tropical environments, from $24^{\circ} 15^{\prime} 48^{\prime \prime} \mathrm{S}, 46^{\circ} 12^{\prime} 00^{\prime \prime} \mathrm{W}$ to $24^{\circ} 21^{\prime} 12^{\prime \prime} \mathrm{S}, 46^{\circ} 09^{\prime} 00^{\prime \prime} \mathrm{W}$. According to Machado et al. (2003), from summer through fall (December-May) the Park is influenced by the South Atlantic Central Water (SACW). During this period, the shallow waters of the continental shelf that surround the LSMSP respond rapidly to both winds and climatic influences, such as river discharge and the meanderings of eddies formed in the region of the Brazilian Current cyclonic shear. From December through March (summer), the seawater temperature and salinity range from 14.5 to $28.4^{\circ} \mathrm{C}$ and from 34.7 to $35.8 \mathrm{psu}$, respectively. A low-temperature core (of approximately $20^{\circ} \mathrm{C}$ ) occurs at the surface. The SACW, typically present during this season, intersects with the bottom at an average depth of $25 \mathrm{~m}$. Under the seasonal thermocline, isothermal $\left(\mathrm{T} \approx 16^{\circ} \mathrm{C}\right)$ and isohaline $(\mathrm{S} \approx 35.6 \mathrm{psu}$ ) water masses below $20 \mathrm{~m}$ depth indicate the intrusion of the SACW. From 8 to $20 \mathrm{~m}$ depth, the thermocline is intensified and shows a $7^{\circ} \mathrm{C}$ average variation (MACHADO et al., 2003; MIRANDA et al., 2003). According to these authors, in this season (December-May) surface waters move away from the coast generating a local upwelling current because of the intrusion of the SACW in shallow waters. This supports the local transport of biologically important properties (nutrients) from deep to shallow waters.

With the winter cooling (normally beginning in June), the removal of the SACW to depths greater than $50 \mathrm{~m}$ and the intensification of vertical mixing produce marked changes in the thermal and haline structures of the LSMSP. Consequently, the thermocline has a weak vertical gradient. The water mass migrates to the east, far from the shore (MIRANDA et al., 2003).

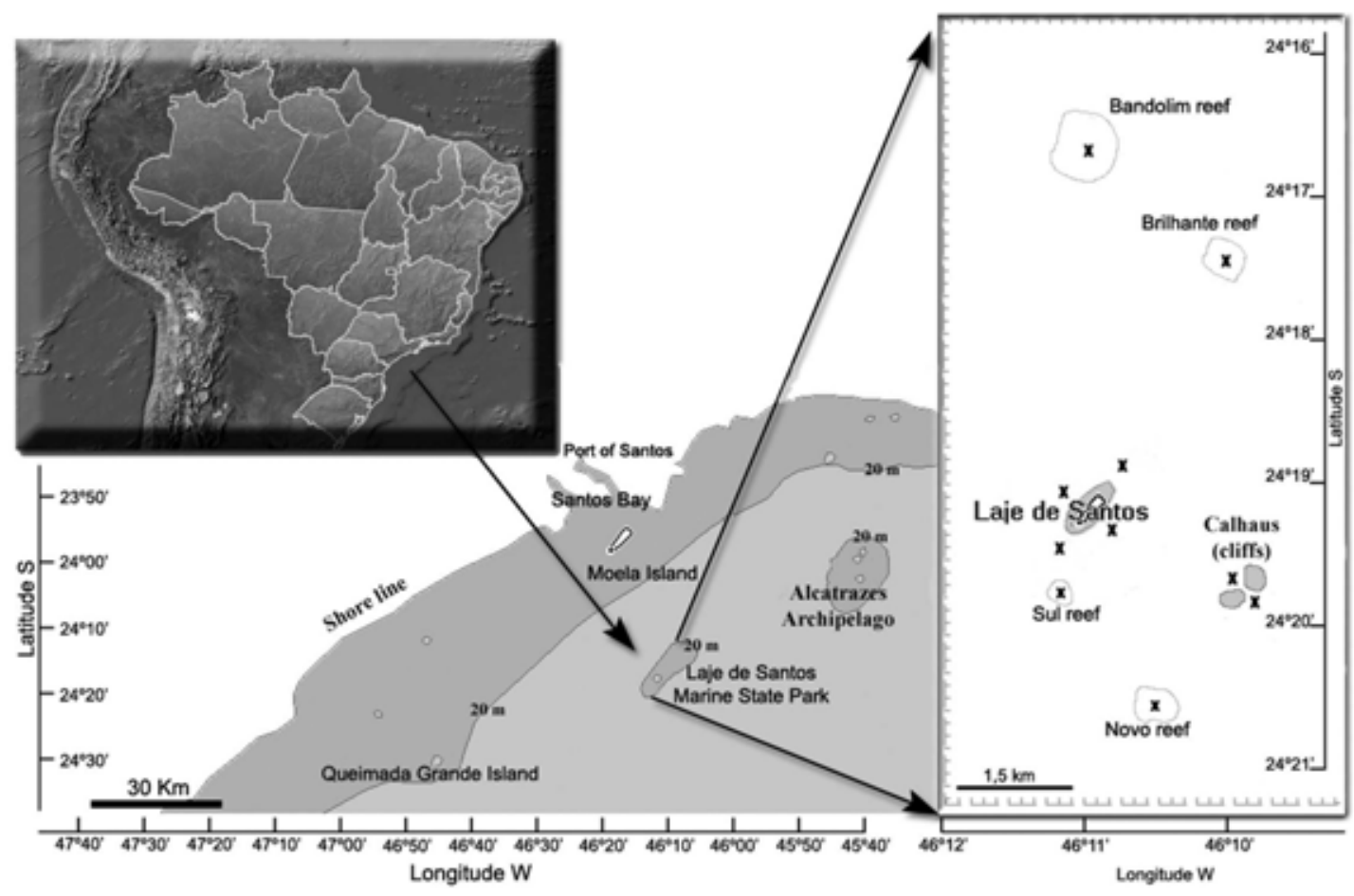

Fig. 1. Southern coast of São Paulo State, showing the Laje de Santos Marine State Park and sampling sites from which macroalgae were collected (X), including bathymetric lines (20 m depth): Laje de Santos, Calhaus, and four reefs (Brilhante, Bandolim, Sul and Novo). 
Sampling

The algae were collected from rocky substrates and the immediately surrounding areas. Their geographical positions were recorded by GPS (WGS 84 datum) on the Laje de Santos $\left(24^{\circ} 19^{\prime} 2.5^{\prime} \mathrm{S}\right.$, 4610'54.8'W), Calhaus (24¹9'45.0's, $46^{\circ} 09^{\prime} 45.5^{\prime \prime} \mathrm{W}$ ) and four reefs (Brilhante (24¹7'24.3"S, $\quad 46^{\circ} 09$ '49.9'W); Bandolim (24¹6'38.0”'S, 46¹0'55.3”W); Sul (24¹9'36.6”S $\left.46^{\circ} 11^{\prime} 07.8^{\prime \prime} \mathrm{W}\right)$ and Novo (24'20'33.4's, $\left.46^{\circ} 10^{\prime} 25.1^{\prime \prime} \mathrm{W}\right)$ ). Samples were collected in the intertidal and subtidal zones of the rocky shore. The subtidal samples were collected by a SCUBA diving team. The collections were made at depths of between 5 and $40 \mathrm{~m}$, by $5 \mathrm{~m}$ depth increments whenever possible. In the intertidal zone, the samplings were undertaken throughout the accessible area of Laje de Santos and Calhaus. In the subtidal zone, 100-150 m long horizontal transects were established at from 5 to $20 \mathrm{~m}$ depth, depending on the intensity of currents and wave heights. But at greater depths, the transects were shorter (of 50-80 m), because they depended on the decompression limits and the amount of decompression gas available. The samples were collected from 2007 through 2009. Each locality (Laje de Santos, Calhaus and the four reefs) was visited twice, once in the summer-fall and once in the winterspring season
Voucher specimens and material for morphological study were fixed in $4 \%$ formalin/seawater or pressed as herbarium sheets. Transverse and longitudinal hand sections were made with a razor blade and stained with $0.5 \%$ aqueous aniline blue solution acidified with $1 \mathrm{~N} \mathrm{HCl}$. Microscopic measurements were made with an ocular micrometer. Photomicrographs were taken with a Sony W5 digital camera (Tokyo, Japan) coupled to a Primo Star Zeiss microscope (Germany). Vouchers of the representative materials were deposited in the Maria Eneyda P.K. Fidalgo Herbarium (SP) of the Botanical Institute, São Paulo, Brazil. Herbarium abbreviations follow Holmgren and Holmgren (2012).

\section{Statistical Analysis}

A multivariate analysis was performed to relate the variations in macroalgal composition to the intrusion of South Atlantic Central Water. The statistical program PC-Ord (version 3.1 for Windows) was applied to a covariance matrix of presenceabsence data. Variables that showed significant correlation and $r>0.5$ on one or two ordination axes were considered in the analysis. To facilitate the reading of the graph, each sample group was replaced by letters (Table 1).

Table 1. Sample groups analyzed in the graph. The sample groups have been replaced by letters to facilitate the reading of the graph. All the species that constitute each sample group are shown in the second column of the table.

\begin{tabular}{|c|c|}
\hline Sample group & Species \\
\hline A & Cladophora montagneana; Halymenia floridana \\
\hline B & Bryopsis plumosa; Chondria leptacremon; Ceratodictyon variabile; Jania crassa \\
\hline $\mathrm{C}$ & Botryocladia wynnei; Champia vieillardii ; Jania capillacea \\
\hline $\mathrm{D}$ & Chondracanthus saundersii; Gelidium torulosum \\
\hline $\mathrm{E}$ & Asteromenia peltata; Botryocladia bahamensis; Chondria platyramea \\
\hline $\mathrm{F}$ & $\begin{array}{l}\text { Derbesia marina; Gelidium sp. 1; Padina gymnospora; Sonderophycus capensis; Peyssonnelia inamoena; Sebdenia } \\
\text { flabellata; Sphacelaria rigidula; } \\
\text { Sphacelaria tribuloides }\end{array}$ \\
\hline G & $\begin{array}{l}\text { Arthrocardia corymbosa; Corallina officinalis; Dictyopteris delicatula; Herposiphonia secunda; Hypnea spinella; } \\
\text { Pseudolithoderma subextensum; } \\
\text { Pterocladiella capillaceae }\end{array}$ \\
\hline $\mathrm{H}$ & $\begin{array}{l}\text { Centroceras clavulatum; Chondracanthus acicularis; Cladophora brasiliana; Ernodesmis verticillata; Jania cubensis; } \\
\text { Porphyra acanthophora; Sargassum cymosum; Sargassum vulgare }\end{array}$ \\
\hline I & Jania subulata \\
\hline $\mathrm{J}$ & Haraldia tenuis \\
\hline $\mathrm{K}$ & Amphiroa beauvoisii; Anotrichium tênue; Feldmannia irregularis; Gloiocladia atlantica; Sargassum platycarpum \\
\hline $\mathrm{L}$ & $\begin{array}{l}\text { Ceramium comptum; Chnoospora mínima; Dictyota bartayresiana; Dictyota menstrualis; Gelidium microdonticum; } \\
\text { Gloiocladia iyoensis; Laurencia marilzae; } \\
\text { Neosiphonia sphaerocarpa }\end{array}$ \\
\hline M & Arthrocardia variabilis; Asparagopsis taxiformis; Cladophora vagabunda; Polysiphonia subtilissima \\
\hline $\mathrm{N}$ & $\begin{array}{l}\text { Cladosiphon occidentalis; Acrochaetium infestans; Colpomenia sinuosa; Hincksia mitchelliae; Neosiphonia } \\
\text { gorgoniae }\end{array}$ \\
\hline $\mathrm{O}$ & Acrosorium ciliolatum; Bryopsis pennata; Hypoglossum anomalum \\
\hline$P$ & $\begin{array}{l}\text { Amphiroa rígida; Asteronema breviarticulatum; Bostrychia tenella; Ceramium brasiliense; Ceramium brevizonatum; } \\
\text { Ceramium sp.; Champia parvula; } \\
\text { Chondria dangeardii; Ceratodictyon planicaule; Ceratodictyon scoparium; Laurencia caraibica; Laurencia } \\
\text { dendroidea; Lomentaria corallicola; Rhodymenia pseudopalmata; Stypopodium zonale; Lithophyllum stictaeforme }\end{array}$ \\
\hline $\mathrm{Q}$ & $\begin{array}{l}\text { Amphiroa anastomosans; Jania sagittata; Codium intertextum; Cryptonemia delicatula; Hypnea musciformis; } \\
\text { Rhizoclonium riparium; Wrangelia argus }\end{array}$ \\
\hline $\mathrm{R}$ & Herposiphonia tenella; Heterosiphonia crispella \\
\hline $\mathrm{S}$ & Lobophora variegata; Pterocladiella caerulescens; Spyridia hipnoides; Ulva lactuca \\
\hline $\mathrm{T}$ & Jania adhaerens; Plocamium brasiliense; Polysiphonia decussata; Sargassum furcatum; Valonia macrophysa \\
\hline $\mathrm{U}$ & Cladophora rupestris \\
\hline
\end{tabular}


To assess the richness of the Park area, the summary of macroalgal taxa cited for LSMSP was compared with the number of species cited for the surrounding areas and the coast of Brazil as a whole.

\section{Hydrodynamic Analysis}

The LSMSP surface currents were computed with a three-dimensional hydrodynamic numerical model implemented by Harari and Camargo (1997, 1998, 2003) and Harari et al. (2006) by analyzing the coastal circulation and its correlation with biological patterns. The model considers the coastal circulation forced by tides, winds and density effects. The wind data were taken from the global atmospheric model of the National Center for Environmental Prediction / National Center for Atmospheric Research (NCEP / NCAR), regularly available on the Internet (KALNAY et al., 1996). Tidal and density effects were included by using available global data banks. The hydrodynamic model was processed for the complete years of 2005, 2007 and 2008 to provide values for currents at grid points with corresponding intensity, direction and the EW and NS components both at the surface and at 5 and $10 \mathrm{~m}$ depth. An advection and diffusion particle program was linked to the hydrodynamic model to compute particle positions subject to turbulence effects and current transport at the same layers of the water column (surface, 5 and 10 $\mathrm{m}$ depth). These depths were chosen because ballast water is discharged at the surface and, to contemplate the specimens present on ship hulls, we used 5 and 10 $m$ depth, because the maximum draft that operates in the Port of Santos is $12 \mathrm{~m}$. Twenty-five points were selected in the region between LSMSP and Santos Bay for the particle release, at the rate of one each hour at each depth (Table 2, Fig. 2). The trajectories of the particles $(n=720$ or 744$)$ were analyzed with a graphical visualization program in the MATLAB computational environment (version 6.5). These particle trajectories allowed us to determine the influence of currents as vectors for transporting organisms from adjacent areas to the Park. The analysis incorporated the most diverse environmental conditions in the processing of the trajectories, e.g. spring and neap tides, summer and winter conditions, calm and windy periods and the intrusion of cold fronts.

\section{RESULTS}

Macroalgal Composition

The present study identified 116 taxa of macroalgae, with 31 new recordings for LSMSP, 11 for Sao Paulo State, 4 for Brazil, 1 for the western Atlantic and 1 for the South Atlantic Ocean, in addition to the possible occurrence of one new species of red alga Osmundea (Rhodomelaceae) and another new red algae genus belonging to the Ceramiaceae. By adding this taxon number to those reported by Amado Filho et al. (2006) and Coto and Pupo (2009), we obtained a total of 184 species present in the Laje de Santos Marine State Park. These species represent approximately $52 \%$ of those known in São Paulo State and are distributed as follows: 22 Chlorophyta, 24 Heterokontophyta and 138 Rhodophyta (Appendix 1). The highest number of taxa is present on the main rock (Laje de Santos).

Table 2. Locations of points where particles were released, in the advection - diffusion simulations. The trajectories were analyzed by graphical visualization program in Matlab.

\begin{tabular}{ccc}
\hline \hline Point & Longitude (W) & Latitude (S) \\
\hline 01 & 46.347404 & 24.032259 \\
02 & 46.305045 & 24.095020 \\
03 & 46.262687 & 24.157780 \\
04 & 46.186442 & 24.102865 \\
05 & 46.186442 & 24.314681 \\
06 & 46.415177 & 24.314681 \\
07 & 46.144083 & 24.314681 \\
08 & 46.186442 & 24.275456 \\
09 & 46.186442 & 24.353906 \\
10 & 46.228800 & 24.314681 \\
11 & 46.101725 & 24.314681 \\
12 & 46.186442 & 24.236230 \\
13 & 46.186442 & 24.393132 \\
14 & 46.271159 & 24.314681 \\
15 & 46.059367 & 24.314681 \\
16 & 46.186442 & 24.197005 \\
17 & 46.186442 & 24.416667 \\
18 & 46.313517 & 24.314681 \\
19 & 46.017008 & 24.314681 \\
20 & 46.186442 & 24.157780 \\
21 & 46.355875 & 24.314681 \\
22 & 46.017008 & 24.157780 \\
23 & 46.355875 & 24.157780 \\
24 & 46.017008 & 24.416667 \\
25 & 46.355875 & 24.416667 \\
\hline & & \\
& Floristic Analysis & \\
\hline & &
\end{tabular}

The covariance matrix analysis showed that the species richness is greater during the summer-fall (December-May) than during the winter-spring season (June-November), with high explanatory power for the two graphical axes (Fig. 3). It is possible to note in this figure that richness is higher on the upper part of axis 2 (positive values), which corresponds to the summerfall period (SF) when the SACW is present in the Park area. For both axes (1 and 2), the broken-stick eigenvalue, which describes the relative abundance of species in relation to environmental variables (in the present study, presence/absence of SACW), was lower than the reference eigenvalue (Table 3 ). According to Jackson (1993), this outcome indicates that the axes contain more information than that expected as due to chance and must therefore be considered in the interpretation of the data. 


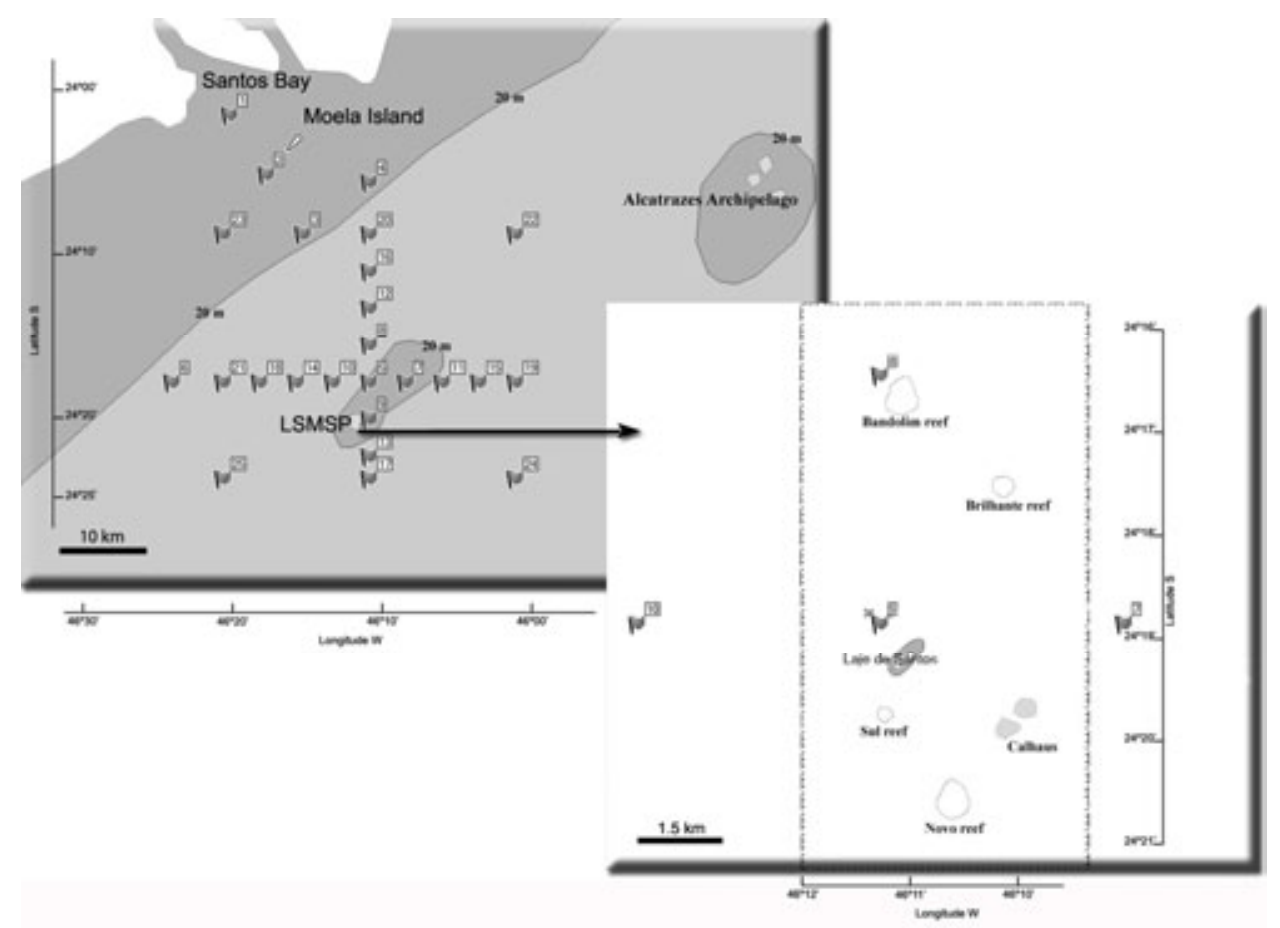

Fig. 2. Points for particle release in the advection - diffusion numerical simulations (1 to 25), including bathymetric lines (20 $\mathrm{m}$ depth).

Table 3. Variance values. Note that, for each axis, the Broken-stick eigenvalue was lower than that found for the eigenvalue.

\begin{tabular}{ccccc}
\hline \hline Axis & Eigenvalue & Percentage of variance & Accumulated variance & Broken-stick Eigenvalue \\
\hline 1 & 93.296 & 41.821 & 41.821 & 10.713 \\
2 & 40.839 & 18.387 & 60.128 & 8.685
\end{tabular}

A comparison of the known macroalgal richness of Santos Bay with the macroalgal richness found in this study for LSMSP reveals large differences in the numbers of taxa (Fig. 4). Moreover, the richness value found for the Park is greater than that reported by Horta et al. (2001), who summarize the composition cited in Horta's PhD thesis for some islands in São Paulo state, for the island closest to the Park: Queimada Grande (Fig. 5). A data compilation from studies of the São Paulo State shore (UGADIM, 1973a, 1973b, 1974, 1975; 1976; HORTA et al. 2001) reveals that LSMSP has greater species richness than most coastal regions of the State (Fig. 6). Fujii et al. (2008) summarized the number of macroalgal taxa described for Brazil. A comparison of this result with the data obtained in the present study shows that the Park has $25 \%$ of the macroalgal species represented in Brazil.
Hydrodynamic Analysis

The dispersion (advection and diffusion) model results indicate that there is almost no influence of particles from the interior of Santos Bay on the Park, as shown in Figure 7. The occurrence of such an influence would be a rare event because the waters from the Bay do not reach the LSMSP área, but tend to flow parallel to the coast. Points $3,4,7,10,11,20$, 22 and 23 have a considerable influence on the dispersion of particles into the Park region. This dispersion changes significantly at particular times of the year. This finding shows that the points cited are important to the seasonal dispersion to the LSMSP (Figs 8-10). The influence of the other points depends on their proximity to the Park. Regardless of its geographical position, a point closer to the Park has more influence on the dispersion of particles to the Park region. 


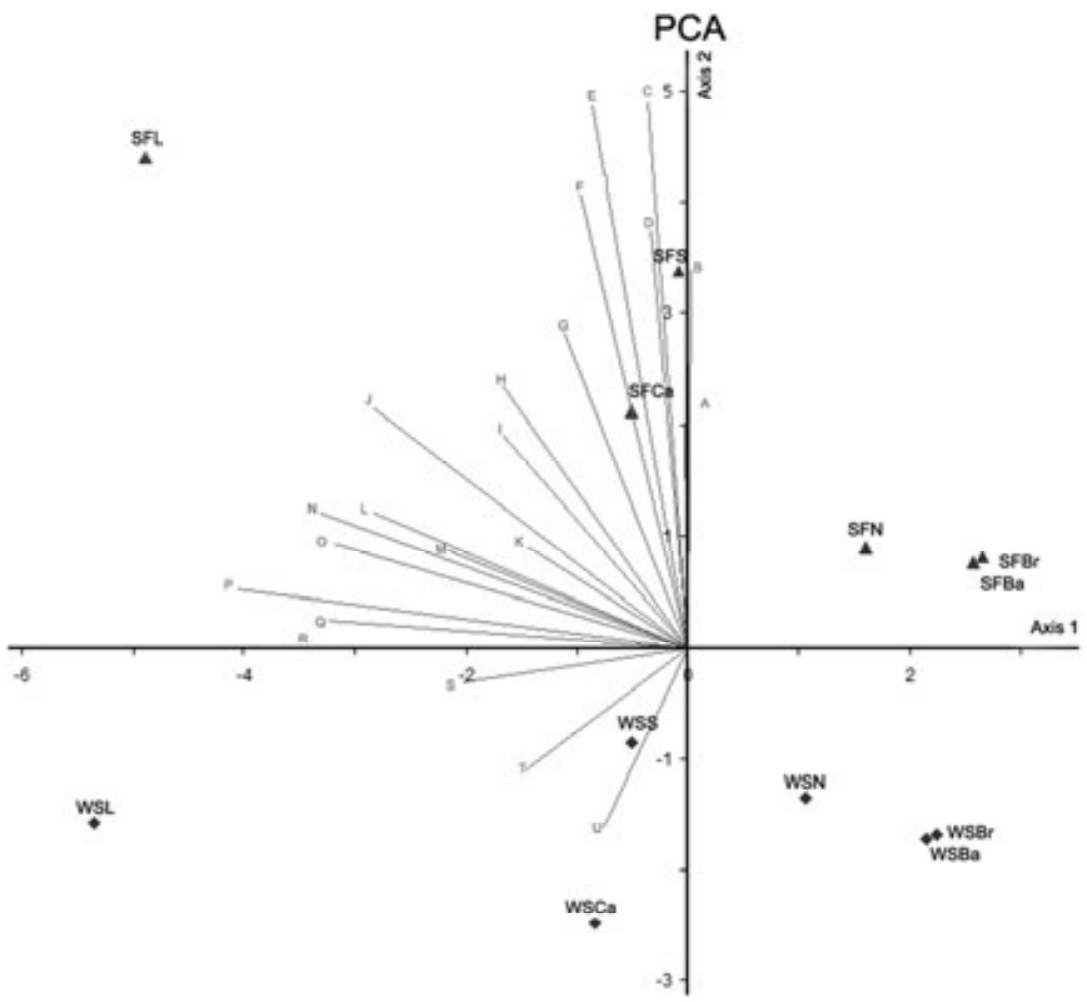

Fig. 3. Covariance matrix analysis. Sampling seasons: Summer/Fall - SF (triangle); Winter/Spring - WS (diamond). Sampling points: L: Laje de Santos; Ca: Calhaus; S: Sul reef; N: Novo reef; Ba: Bandolim reef; Br: Brilhante reef. In this figure is possible note that richness is higher on superior part of the axis 2 (positive values), which correspond to the summer-fall period (SF) when the SACW is present in the Park area.

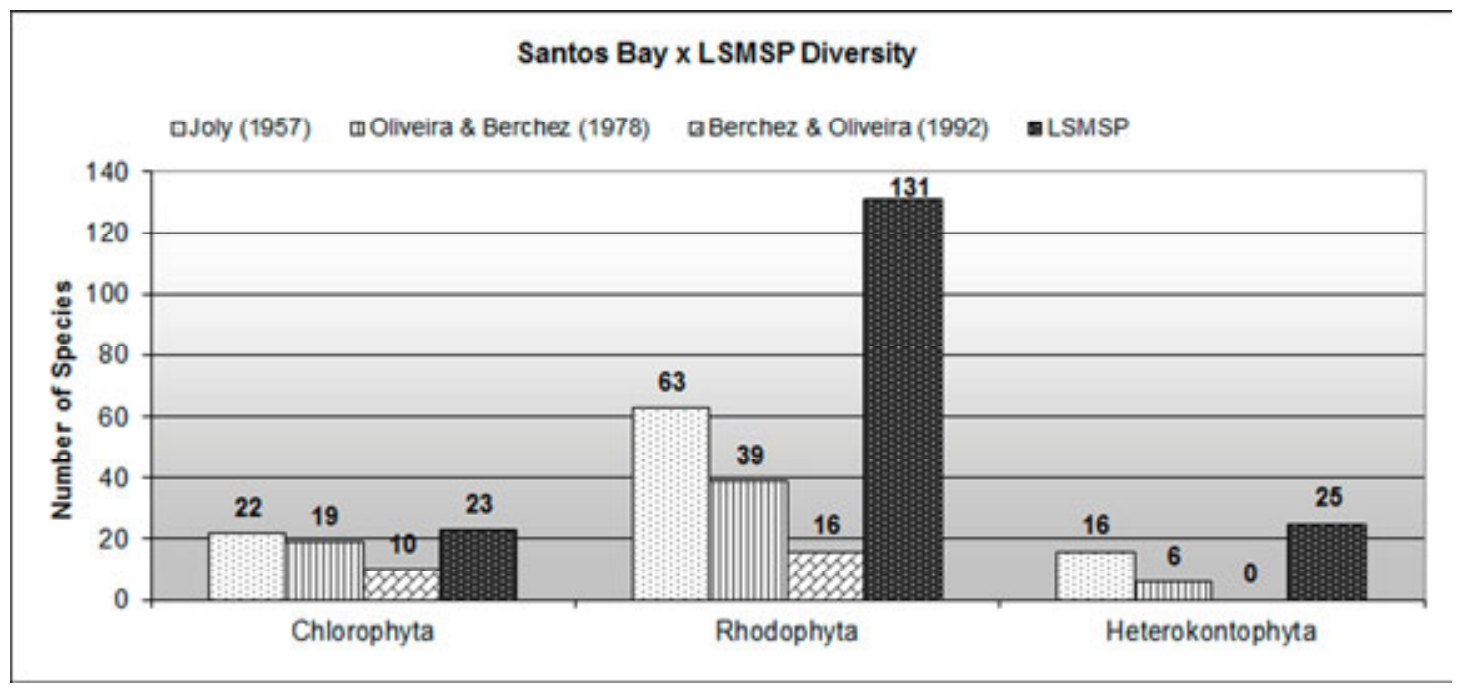

Fig. 4. Comparison of the known macroalgal richness of Santos Bay with LSMSP. 


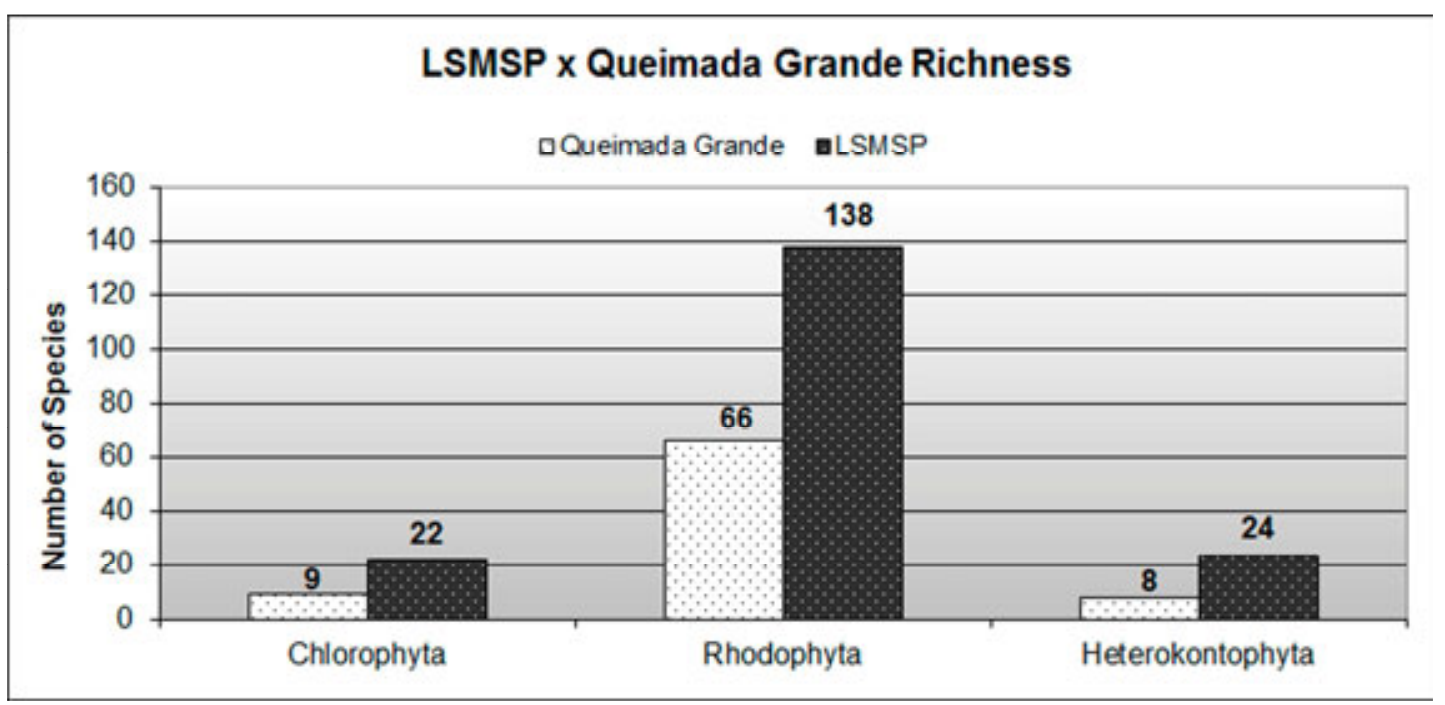

Fig. 5. Comparison of the known macroalgal richness of Queimada Grande Island with LSMSP.

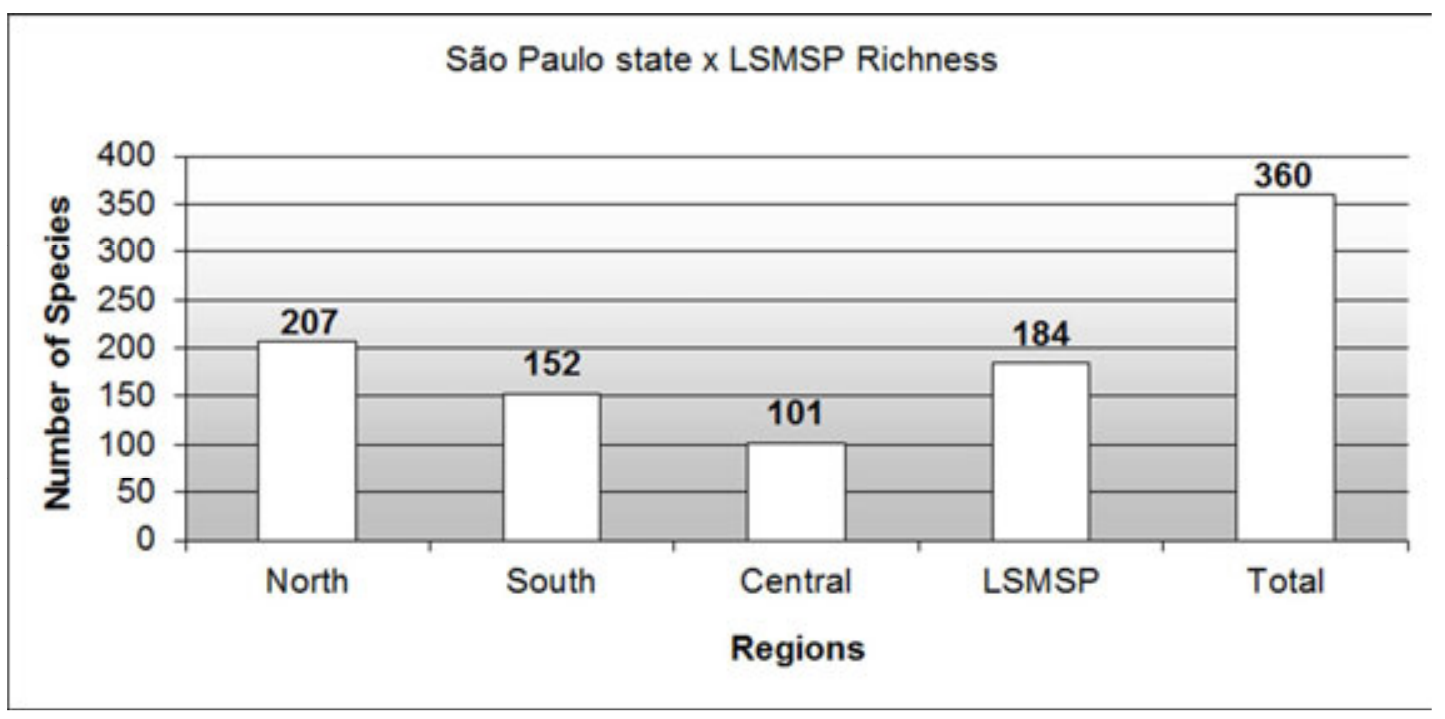

Fig. 6. Comparison of the known macroalgal richness of São Paulo State, specified by regions (north, central and south) with LSMSP. 

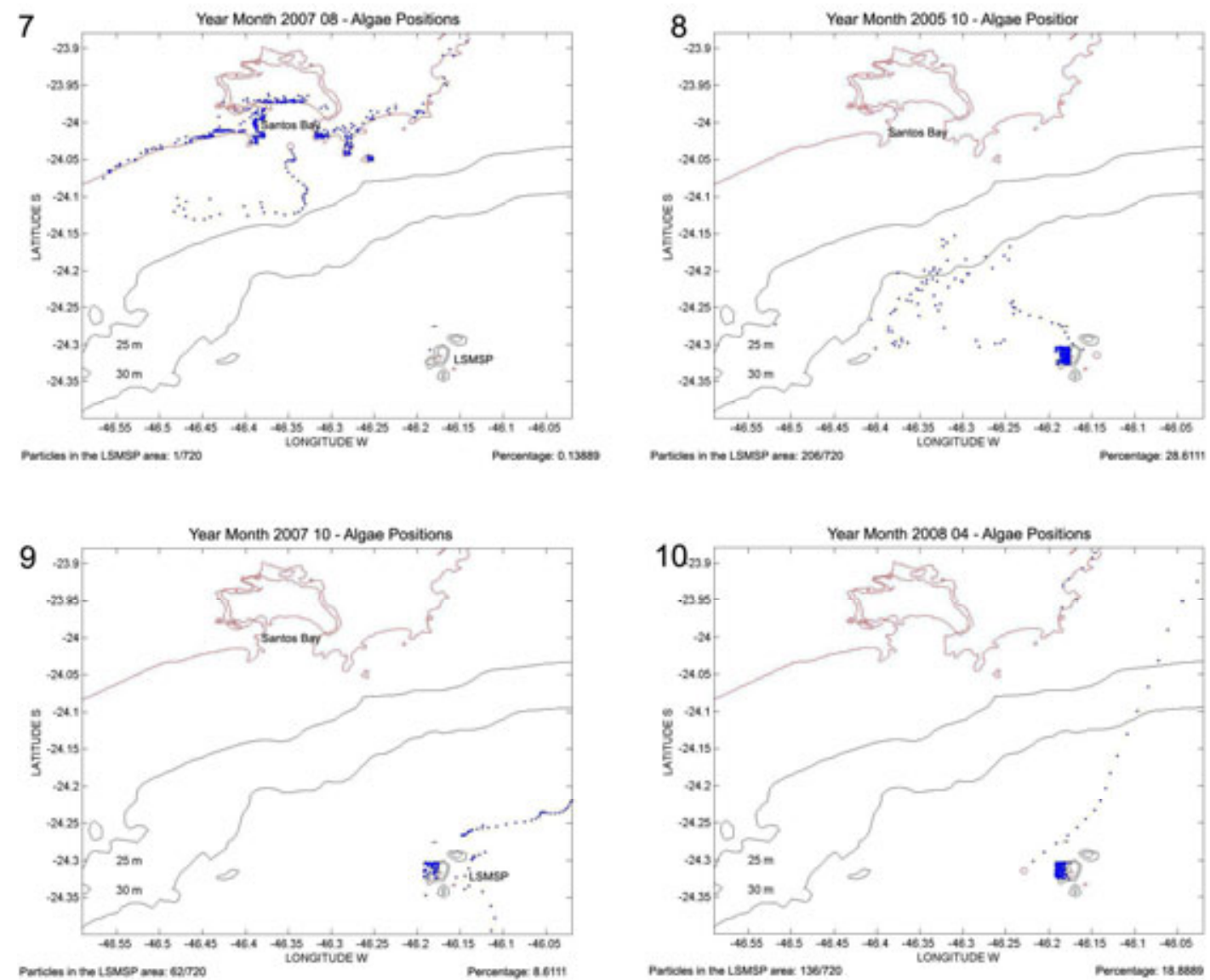

Figs 7, 8, 9 and 10. Particle advection and diffusion at the surface. Lower left corner: the number of particles released by the program and the amount that reach the Park area ("Particles in LSMP area"). Lower right corner: the percentage of particles that reach the park ("Percentage").

\section{DisCUSSION}

Laje de Santos Marine State Park is an important area for macroalgal diversity. Based on Fujii et al. (2008), the Park contains $25 \%$ of the taxa described for the whole Brazilian coast. The species richness of the Park is greater than that of most coastal regions of Sao Paulo State. As we have shown above, the highest number of taxa was found on the main rock rather than on the cliffs and reefs. It is probable that this difference resulted from the diversity of habitats and substrata available for the settlement of organisms (NEVES, 1997).

The macroalgal richness is highest during the summer-fall season, something that could easily be observed in situ, during the sampling. The value of richness is highly correlated with the presence of South Atlantic Central Water in the Park area, as supported by the statistical results. This water mass thermally stratifies the environment, generating two distinct zones in the water column. Warm waters occur near the surface, and extremely cold waters occur at the bottom. This stratification provides, as mentioned by Machado et al. (2003), an increase of nutrient availabilty to the ecosystem and could enhance the conditions favoring the development of some taxa.

As mentioned above, Machado et al. (2003) affirmed that the basic hydrographic characteristics of LSMSP ( $\mathrm{pH}$, temperature, salinity and wave exposure) are similar to those found in other regions of the São Paulo coast. Moreover, other conservation units on the coast of São Paulo State (not marine parks) have lower macroalgal richness than LSMSP. Exploitation is also forbidden in these other areas. Some of these units consist of islands (where the influence of SACW is higher) which are much better supervised by the governmental agencies than the Park area. The difference of sampling effort between this study and the others could be one explanatory factor for the difference in richness but, probably, there are also 
others. The presence of ships near the LSMSP is one of the outstanding differences between the Park and the other units. The analysis of the dispersion data shows that the currents can transport particles, which originally arrived on vessels traveling from other regions, to the LSMSP. Point 22, which has a significant influence on the Park area at certain times of the year, is on the main route used by the vessels that enter the Port area. Owing to the lack of adequate surveillance, these vessels dump their ballast water in the marine environment while they are underway. In addition, almost all the area surrounding the Park e.g. points 7 and 10, is where ships anchor to await permission to enter Santos Bay. While the ships are waiting, their hulls are cleaned. Much of their ballast water is jettisoned and allows the release of organisms into the marine environment. This hypothesis is supported by the studies by Dromgoole (1975), Carlton and Scanlon (1985) and Campbell (1999) on the introduction of Codium fragile (Suringar) Hariot into, respectively, the North Atlantic, Australia and New Zealand. Some specimens were present on the ships' hulls, and others originated from propagules present in the ballast tanks. Flagella et al.(2007) analyzed the ballast tanks of 12 ships in two ports of the Mediterranean Sea and found 15 taxa of macroalgae, 11 belonging to the genus Ulva Linnaeus and two belonging to the Heterokontophyta. Nyberg and Wallentinus (2009) tested the survival and growth of Gracilaria vermiculophylla (Ohmi) Papenfuss (Rhodophyta), sampled on the Swedish coast and kept in the complete absence of light and at $4^{\circ} \mathrm{C}$ from 4 to 175 days. After this period, the algae were placed in salt water (with two different salinities, 26 and $35 \mathrm{psu}$ ) at $11.5{ }^{\circ} \mathrm{C}$. All the algae survived and continued to grow regardless of the lapse of time from the beginning of the experiment. The ecotoxicological analysis performed by Abessa et al. (2005) showed that the contaminants present in the Park are, probably, due to the washing of ship tanks. We may suppose that these species in the LSMSP area find suitable habitats for their growth there, where the habitats differ substantially from those in Santos Bay or located on the coast line. The Bay and its surrounding areas show only a minor influence of the SACW during the summer, and they are frequently subjected to large amounts of pollutants that originate in the Port. However, further study, such as would, for example, check whether some macroalgae taxa present at the Park area are found in the ballast tanks of ships that use the Port of Santos, is necessary to verify this hypothesis. We ourselves have started a new study (August, 2011), sampling the ballast tanks of ships in the Port of Santos, filtering the water $(0.45 \mu \mathrm{m}$ size pore and $47 \mathrm{~mm}$ diameter) and cultured the filters. We have so far identified two taxa of macroalgae (data not published), collected in just one ship. Unfortunately, it is difficult to gain access to ships in Brazilian waters because of the bureaucracy involved in such access and also because ship owners further complicate it for fear that the data might lead to prosecution by environmental agencies.

The comparison between the macroalgal richness in the Park and in other areas highlights the importance of LSMSP. Possibly the difference in richness between the Park and Santos Bay is influenced by two factors, among others. First, the SACW intrusion in summer is much more pronounced in the Park area than in the Bay and provides the Park area with the benefits of the SACW cited above. Further, as shown by the dispersion model, hardly any water from the Bay reaches the Park. These patterns of circulation prevent pollutants from the Port reaching the conservation unit. Abessa et al. (2005) undertook ecotoxicological tests in the Park waters, and the amount of pollutants found was much smaller than that described for the Santos Bay, as they are from different sources. It is probable that the higher macroalgal richness described for LSMSP than for Queimada Grande island results from the greater sampling effort applied in the present study. Only two samples were collected from Queimada Grande Island by Horta et al. (2001). However, Horta et al. (2001) also collected two samples in LSMSP from the main rock and found greater macroalgal richness there than at Queimada Grande island. So other factors such as the diversity of habitats (LSMSP has a higher number of rocky substrata than Queimada Grande island, mainly in the subtidal zone), the presence of pollutants (Queimada Grande is closer to the coastline than LSMSP - which could be increasing the amount of pollutants in the Queimada Grande area), among others, must be contributing to this difference. Further study is necessary to ascertain which factors really lie behind this difference.

Another point which must be checked is the real importance of SACW to the macroalgal composition. The results of this study show there is a correlation between the presence of the water mass and macroalgal richness, mainly because this latter is greater when the SACW is acting in the region, but what of the role of other factors such as trophic relationships, presence or absence of predators and refuge from fishing? Thus further study is necessary to verify the interaction of these factors and their influence on the local environment.

Owing to the great richness of the macroalgae, the LSMSP is an important bank of germplasm for the surrounding ecosystems. Its species variability structures the environment, which not only supports local fishing but also provides an important economic resource in the form of tourism (NEVES, 1997). It is necessary to develop and implement a management plan for this Conservation Unit to 
monitor not only illegal exploitation in the Park but also underwater tourist activities. If these activities are not controlled they could harm the Park's benthic communities and cause their richness to be lost, as demonstrated for other areas by Hawkins and Roberts (1992), Dixon et al. (1993), Davis and Tisdell (1996) and MMA (2002). Any severe impact on this ecosystem will damage not only its organisms but also the human populations that depend directly or indirectly on the ecosystem of the Park.

\section{REFERENCES}

ABESSA, D. M. S.; ZARONI, L. P.; SOUSA, EDUINETTY, C. P. M.; GASPARRO, M. R.; PEREIRA, SEABRA, C. D.; RACHID, B. R. F. ; DEPLEDGE, M. ; KING, R. S. Physiological and cellular responses in two populations of the mussel Perna perna collected at different sites from the coast of São Paulo, Brazil. Braz. Arch. Biol.Tech., v. 48, p. 217-225, 2005.

AMADO FILHO, G. M.; HORTA, P. A.; BRASILEIRO, P. S.; BARROS-BARRETO, M. B. B. and FUJII, M. T. Subtidal benthic marine algae of the Marine State Park of Laje de Santos (São Paulo, Brazil). Braz. J. Oceanogr. v. 54, p. 225-234, 2006.

BAGGERMAN, B. Spatfall and transport of Cardium edule Archs Neerl. Zool., v. 10, p. 315-342, 1953

BAILEY, S. A.; DUGGAN, I. C.; JENKINS, P. T.; MACISAAC, H. J. Invertebrate resting stages in residual ballast sediment of transoceanic ships. Can. J. Fish.Aquat. Sci,v. 62, n. 5, p. 1090-1103, 2005.

BAYNE, B. L. Primary and secondary settlement in Mytilusedulis. L. (Mollusca). J. Anim. Ecol.,v. 33, p. 513-523, 1964.

BERCHEZ, F. A. S.; OLIVEIRA, E. C. Temporal changes in the benthic marine flora of the Baía de Santos, SP, Brazil, over the last four decades. In: CORDEIROMARINO, M.; AZEVEDO, M.T.P.; SANT'ANNA, C.L.; YAMAGUSHI-TOMITA, N.; PLASTINO, E.M. (Ed.). Algae and environment: a general approach. São Paulo: Sociedade Brasileira de Ficologia, p. 120-125, 1992.

BEUKEMA, J. J.; DE VLAS, J. Tidal-current transport of thread-drifting post larval juveniles of the bivalve Macoma balthica from the Wadden Sea to the North Sea. Mar. Ecol. Progr. Ser., v. 52, p. 193-200, 1989.

BIBER, P. D. Hydrodynamic transport of drifting macroalgae through a tidal cut. Estuar. Coast. Shelf Sci., v. 74, n. 3, p. 565-569, 2007.

BIJ DE VAATE, A. Some evidence for ballast water transport being the vector of the Quagga mussel (Dreissena rostriformis bugensis Andrusov, 1897) introduction into Western Europe and subsequent upstream dispersal in the River Rhine. Aquat. Inv, v. 5 , n. 2, p. 207-209, 2010

BONSDORFF, E. Drifting algae and zoobenthos - Effects on settling and community structure. Neth. J. Sea Res., v. 30, p. 57-62, 1992.

CAMPBELL, S. J. Occurrence of Codium fragile subsp. tomentosoides (Chlorophyta: Bryopsidales) in marine embayments of Southeastern Australia. J. Phycol., v. 35, p. $938-940,1999$.
CARLTON, J. T.; SCANLON, J. A. Progression and dispersal of an introduced alga Codium fragile spp. tomentosoides (Chlorophyta) on the Atlantic coast of North America. Bot. Mar., v. 28, p. 155-65, 1985.

COTO, A. C. S. P.; PUPO, D. Ulvophyceae. São Carlos, SP: RIMA, 2009. $86 \mathrm{p}$

DAVIS, D.; TISDELL, C. Economic management of recreational SCUBA DIVING and the environment. J. Environ. Manage., v. 48, p. 229-248, 1996.

DIXON, J. A.; SCURA, L. F.; VAN'T HOF, T. Meeting ecological and economic goals: Marine Parks in the Caribbean. Ambio, v. 22, p. 117-125, 1993.

DROMGOOLE, F. I. Occurrence of Codium fragile subsp. tomentosoides in New Zealand waters. N. Z. J. Mar. Freshw. Res., v. 9, p. 257-64, 1975.

FLAGELLA, M. M.; VERLAQUE, M.; SORIA, A and BUIA, M. C. Macroalgal survival in ballast water tanks. J. Mar. Pollut. Bul., v. 54, p. 1395-401, 2007.

FUJII, M. T.; BARATA, D.; CHIRACAVA, S.; GUIMARÃES, S. M. P. B. Cenário brasileiro da diversidade de algas marinhas bentônicas e sua contribuição para a política de conservação dos recursos naturais e do meio ambiente. In: LOIOLA, M. I. B.; BASEIA, I. G.; LICHSTON, J. E. (Org.) ANAIS DO 59 CONGRESSO BRASILEIRO DE BOTÂNICA: ATUALIDADES, DESAFIOS E PERSPECTIVAS DA BOTÂNICA NO BRASIL, 59, 2008. Anais... Rio Grande do Norte: Imagem Gráfica, 2008. p. 375-377.

GRAY, D. K.; MACISAAC, H. J. Diapausing zooplankton eggs remain viable despite exposure to open-ocean ballast water exchange: evidence from in situ exposure experiments. Can. J. Fish. Aquat. Sci., v. 67, n. 2, p. 417-426, 2010.

HARARI, J.; CAMARGO, R. Simulações da circulação de maré na região costeira de Santos (SP) com modelo numérico hidrodinâmico. Pesquisa Naval. Rev. Marit. Bras., v. 10, p. 173-188, 1997.

HARARI, J.; CAMARGO, R. Modelagem numérica da região costeira de Santos (SP): circulação de maré. Rev. Bras.Oceanogr., v. 46, n. 2, p. 135-156, 1998.

HARARI, J:CAMARGO, R. Numerical simulation of the tidal propagation in the coastal region of Santos (Brazil, $\left.24^{\circ} \mathrm{S} 46^{\circ} \mathrm{W}\right)$. Cont. Shelf Res., v. 23, p. 1597- 1613, 2003.

HARARI, J.; CAMARGO, R.; FRANÇA, C. A. S.; MESQUITA, A. R.; PICARELLI, S. S. Numerical modeling of the hydrodynamics in the coastal area of Sao Paulo State - Brazil. J. Coast. Res., v. 39, p. 1560- 1563, 2006.

HAWKINS, J. P.; ROBERTS, C. P. Effects of recreational SCUBA diving on fore-reef slope communities of coral reefs. Biol. Conserv., v. 26, p. 171-178, 1992.

HOLMGREN, P. K. and HOLMGREN, N. H. Index Herbariorum: A global directory of public herbaria and associated staff. New York Botanical Garden's Virtual Herbarium, 2012. Available <http://sweetgum.nybg.org/ih>. Accessed 15 may 2012.

HORTA, P. A. Considerações sobre a origem e distribuição da flora de macroalgas marinha brasileira. Hoehnea, v. 3, p. 243-265, 2001.

JACKSON, D. A. Stopping rules in principal componentsanalysis - a comparison of heuristic and statistical approaches. Ecology, v. 74, n. 8, p. 2204-2214, 1993. 
JOLY, A. B. Contribuição ao conhecimento da flora ficológica marinha da baía de Santos e arredores. Boletim da Faculdade de Filosofia, Ciências e Letras, Universidade de São Paulo, n. 217, 1957, 393 p. (Botânica).

KALNAY, E; KANAMITSU, M; KISTLER, R ; COLLINS, W.; DEAVEN, D.; GANDIN, L; IREDELL, M.; SAHA S.; WHITE, G.; WOOLLEN, J.; ZHU, Y.; CHELLIAH, M.; EBISUZAKI, W.; HIGGINS, W.; JANOWIAK, J.; MO, K.C.; ROPELEWSKI, C.; WANG, J.; LEETMAA, A.; REYNOLDS, R.; JENNE, R.; JOSEPH, D. The Ncep/Ncar 40-year reanalysis project. Bull. Am. Meteorol. Soc., v. 77, p. 437-470, 1996.

LUIZ-JUNIOR, O.; CARVALHO-FILHO, A.; FERREIRA, C. E. L.; FLOETER, S. R.; GASPARINI, J. L.; SAZIMA, I. The reef fish assemblage of the Laje de Santos Marine State Park, Southwestern Atlantic: annotated checklist with comments on abundance, distribution, trophic structure, symbiotic associations, and conservation. Zootaxa, n. 1807, p. 1-25, 2008

MACHADO, M. B.; HARARI, J.; OLIVEIRA, M. R. Projeto Vida na Laje: Levantamento preliminar biológico e oceanográfico da área do Parque Estadual Marinho da Laje de Santos. In: CONGRESSO BRASILEIRO DE PESQUISAS AMBIENTAIS E SAÚDE - CBPAS, 3. Santos, SP, 2003. v. 1, p. 1-4,

MMA - Ministério do Meio Ambiente. Cadastro nacional de unidades de conservação. Brasília: 2011. Available <http://www.mma.gov.br>. Accessed 12 April 2011.

MMA- Ministério do Meio Ambiente. Avaliação e ações prioritárias para a conservação da biodiversidade das zonas costeira e marinha. Biodiversidade Brasileira: Avaliação e identificação de áreas prioritárias para conservação, utilização sustentável e repartição de benefícios da biodiversidade brasileira. Brasília: 2002. (Série Biodiversidade, v. 5, 404 p.)

MIRANDA, L. B.; CASTRO, B. M.; REZENDE, L. F.; MELLO, R. L. Variação Sazonal de propriedades hidrográficas ao largo do Parque Estadual Marinho Laje de Santos (SP). In: CONGRESSO BRASILEIRO DE PESQUISAS AMBIENTAIS E SAÚDE - CBPAS, 3. Santos, SP, 2003. v. 1, p. 1-4, 2003.

NEVES, T. Dossiê de gerenciamento do Parque Estadual Marinho da Laje de Santos, São Paulo. São Paulo: Instituto Florestal, Secretaria do MeioAmbiente, 1997. v.1-2, $425 \mathrm{p}$
NYBERG, C. D.; WALLENTINUS, I. Long-term survival of an introduced red alga in adverse conditions. Mar. Biol. Res., v. 5, n. 3, p. 304-308, 2009.

OLIVEIRA, E.C.; BERCHEZ, F.A.S. Algas marinhas da Baía de Santos - alterações da flora no período de 19581978. Bol. Bot. Univ. S. Paulo, v. 6, p. 49-60, 1978.

RENAUD-DEBYSER, J.; SALVAT, B. Eléments de prospérité des biotopes des sediments meubles intertidaux et écologie de leurs populations en microfaune et macrofaune. Vie Milieu, v.14, n. 3, p. 463-550, 1963.

SECRETARIA DE PORTOS. Relatório Anual e Demonstrações Contábeis 2010, 2011. Santos, SP: Codesp. Available <http://www.portodesantos.com.br>. Accessed 20 August 2011.

UGADIM, Y. Algas marinhas bentônicas do litoral sul do Estado de São Paulo e do litoral do estado do Paraná. I Divisão Chlorophyta. Bol. Bot. Univ. Sao Paulo, v.1, p. 11-77, 1973a.

UGADIM, Y. Algas marinhas bentônicas do litoral sul do estado de São Paulo e do litoral do estado do Paraná. II Divisão Phaeophyta. Portugaliae Acta Biol., v. 12, p. 69-131, 1973b.

UGADIM, Y. Algas Marinhas Bentônicas do Litoral Sul do Estado de São Paulo e do Litoral do estado do Paraná. III - Divisão Rhodophyta (1) Goniotricales, Bangiales, Nemaniolales e Gelidiales. Bol. Bot. Univ. Sao Paulo, v. 2, p. 93-137, 1974.

UGADIM, Y. Algas Marinhas Bentônicas do Litoral Sul do Estado de São Paulo e do Litoral do estado do Paraná. III - Divisão Rhodophyta (2): Cryptonemiales, Gigartinales e Rhodymeniales. Bol. Bot Univ Sao Paulo, v. 3, p. 115164, 1975.

UGADIM, Y. Ceramiales (Rhodophyta) do litoral Sul do estado de São Paulo e do Litoral do Estado do Paraná (Brasil). Bol. Bot. Univ. Sao Paulo, v. 4, p. 133-172, 1976.

(Manuscript received 03 April 2012; revised 26 August 2012; accepted 28 August 2012)

Appendix 1

Taxa list of Laje de Santos Marine State Park, summarizing knowledge of the macroalgal composition presented in Amado Filho et al. (2006), Coto and Pupo (2009) and the present study.

\begin{tabular}{|c|c|c|c|}
\hline Taxa & $\begin{array}{c}\text { Amado Filho et al. } \\
\text { (2006) }\end{array}$ & $\begin{array}{c}\text { Coto and Pupo } \\
(2009)\end{array}$ & Present study \\
\hline \multicolumn{4}{|l|}{ CLOROPHYTA } \\
\hline \multicolumn{4}{|l|}{ BRYOPSIDALES } \\
\hline Bryopsis pennata J.V. Lamouroux & $X$ & $\mathrm{x}$ & $\mathrm{x}$ \\
\hline Bryopsis plumosa (Hudson) C. Agardh & $\mathrm{X}$ & $\mathrm{x}$ & $\mathrm{x}$ \\
\hline Codium intertextum F.S. Collins \& Hervey & $\mathrm{X}$ & $\mathrm{x}$ & $\mathrm{x}$ \\
\hline Derbesia marina (Lyngbye) Solier * & & & $\mathrm{x}$ \\
\hline \multicolumn{4}{|l|}{ CLADOPHORALES } \\
\hline Chaetomorpha antennina (Bory de Saint-Vincent) Kützing & & $\mathrm{x}$ & $\mathrm{x}$ \\
\hline Chaetomorpha linum (O.F. Müller) Kützing & $X$ & & \\
\hline Cladophora brasiliana $\mathrm{G}$. Martens & & $\mathrm{x}$ & $\mathrm{x}$ \\
\hline Cladophora capensis (C. Agardh) De Toni & $\mathrm{X}$ & & \\
\hline
\end{tabular}


Appendix 1. Cont.

\begin{tabular}{|c|c|c|c|}
\hline Taxa & $\begin{array}{l}\text { Amado Filho et al. } \\
(2006)\end{array}$ & $\begin{array}{c}\text { Coto and Pupo } \\
\text { (2009) }\end{array}$ & Present study \\
\hline Cladophora coelothrix Kützing & & $\mathrm{x}$ & \\
\hline Cladophora dalmatica Kützing & & $\mathrm{x}$ & \\
\hline Cladophora montagneana Kützing * & & & $\mathrm{x}$ \\
\hline Cladophora pellucidoidea Hoek & & $\mathrm{x}$ & \\
\hline Cladophora rupestris (Linnaeus) Kützing & & $\mathrm{x}$ & $\mathrm{x}$ \\
\hline Cladophora vagabunda (Linnaeus) Kützing & $\mathrm{x}$ & $\mathrm{x}$ & $\mathrm{x}$ \\
\hline Ernodesmis verticillata (Kützing) Børgesen & $\mathrm{x}$ & & $\mathrm{x}$ \\
\hline Rhizoclonium riparium (Roth) Harvey* & & & $\mathrm{x}$ \\
\hline Valonia macrophysa Kützing & & & $\mathrm{x}$ \\
\hline Valonia utricularis (Roth) C. Agardh & $\mathrm{x}$ & & \\
\hline \multicolumn{4}{|l|}{ ULVALES } \\
\hline Ulva flexuosa Wulfen * & & & $\mathrm{x}$ \\
\hline Ulva lactuca Linnaeus* & & & $\mathrm{x}$ \\
\hline Ulva linza Linnaeus & & $\mathrm{x}$ & \\
\hline Ulva rigida $\mathrm{C}$. Agardh $*$ & & & $\mathrm{x}$ \\
\hline \multicolumn{4}{|l|}{ HETEROKONTOHYTA } \\
\hline \multicolumn{4}{|l|}{ DICTYOTALES } \\
\hline Canistrocarpus cervicornis (Kützing) De Paula \& De Clerk & $\mathrm{x}$ & & $\mathrm{x}$ \\
\hline Dictyopteris delicatula J.V. Lamouroux & $\mathrm{x}$ & & $\mathrm{x}$ \\
\hline Dictyopteris plagiogramma (Montagne) Vickers & $\mathrm{x}$ & & \\
\hline Dictyota bartayresiana J.V. Lamouroux * & & & $\mathrm{x}$ \\
\hline Dictyota menstrualis (Hoyt) Schnetter, Hörning \& Weber-Peukert & $\mathrm{x}$ & & $\mathrm{x}$ \\
\hline Lobophora variegata (J.V. Lamouroux) Womersley ex Oliveira & $\mathrm{x}$ & & $\mathrm{x}$ \\
\hline Padina gymnospora (Kützing) Sonder & $\mathrm{x}$ & & $\mathrm{x}$ \\
\hline Spatoglossum schroederi (C. Agardh) Kützing & $\mathrm{x}$ & & \\
\hline Stypopodium zonale (Lamouroux) Papenfuss ** & & & $\mathrm{x}$ \\
\hline \multicolumn{4}{|l|}{ ECTOCARPALES } \\
\hline Cladosiphon occidentalis Kylin & $\mathrm{x}$ & & $\mathrm{x}$ \\
\hline Feldmannia irregularis (Kützing) G. Hamel & $\mathrm{x}$ & & $\mathrm{x}$ \\
\hline Hincksia mitchelliae (Harvey) P.C. Silva & $\mathrm{x}$ & & $\mathrm{x}$ \\
\hline Nemacystus howei (W.R. Taylor) Kylin & $\mathrm{x}$ & & \\
\hline Pseudolithoderma subextensum (Waern) S. Lund***** & & & $\mathrm{x}$ \\
\hline \multicolumn{4}{|l|}{ FUCALES } \\
\hline Sargassum cymosum $\mathrm{C}$. Agardh * & & & $\mathrm{x}$ \\
\hline Sargassum furcatum Kützing * & & & $\mathrm{x}$ \\
\hline Sargassum platycarpum Montagne ** & & & $\mathrm{x}$ \\
\hline Sargassum vulgare C. Agardh & $\mathrm{x}$ & & $\mathrm{x}$ \\
\hline \multicolumn{4}{|l|}{ SCYTOSIPHONALES } \\
\hline Chnoospora mínima (K. Hering) Papenfuss * & & & $\mathrm{x}$ \\
\hline Colpomenia sinuosa (Mertens ex Roth) Derbès \& Solier * & & & $\mathrm{x}$ \\
\hline \multicolumn{4}{|l|}{ SCYTOTHAMNALES } \\
\hline Asteronema breviarticulatum (J. Agardh) Ouriques \& Bouzon * & & & $\mathrm{x}$ \\
\hline \multicolumn{4}{|l|}{ SPHACELARIALES } \\
\hline Sphacelaria rigidula Kützing * & & & $\mathrm{x}$ \\
\hline Sphacelaria tribuloides Meneghini * & & & $\mathrm{x}$ \\
\hline \multicolumn{4}{|l|}{ SPOROCHNALES } \\
\hline Sporochnus pedunculatus (Hudson) C. Agardh & $\mathrm{x}$ & & \\
\hline \multicolumn{4}{|l|}{ RHODOPHYTA } \\
\hline \multicolumn{4}{|l|}{ ACROCHAETIALES } \\
\hline Acrochaetium infestans M.A.Howe \& Hoyt $* *$ & & & $\mathrm{x}$ \\
\hline Acrochaetium microscopicum (Nägeli ex Kützing) Nägeli & $\mathrm{x}$ & & \\
\hline Acrochaetium savianum (Meneghini) Nägeli & $\mathrm{x}$ & & \\
\hline \multicolumn{4}{|l|}{ BANGIALES } \\
\hline Porphyra acanthophora E.C. Oliveira \& Coll * & & & $\mathrm{x}$ \\
\hline BONNEMAISONIALES & & & \\
\hline Asparagopsis taxiformis (Delile) Trevisan de Saint-Léon & $\mathrm{x}$ & & $\mathrm{x}$ \\
\hline CERAMIALES & & & \\
\hline Acrosorium ciliolatum (Harvey) Kylin & & & $\mathrm{x}$ \\
\hline Acrosorium decumbens (J. Agardh) Kylin & $\mathrm{x}$ & & \\
\hline Aglaothamnion halliae (F.S. Collins) N.E. Aponte, D.L. Ballantine \& & $\mathrm{x}$ & & $\mathrm{x}$ \\
\hline $\begin{array}{l}\text { J.N. Norris * } \\
\text { Aglaothamnion c.f. tenuissimum }\end{array}$ & $\mathrm{x}$ & & \\
\hline Anotrichium tênue (C. Agardh) Nägeli & $\mathrm{x}$ & & $\mathrm{x}$ \\
\hline Anotrichium yagii (Okamura) Nägeli & $\mathrm{x}$ & & \\
\hline Antithamnionella breviramosa (Dawson) Wollaston & $\mathrm{x}$ & & \\
\hline Antithamnion antillanum Børgesen & & & \\
\hline Bostrychia tenella (J.V. Lamouroux) J. Agardh * & & & $\mathrm{x}$ \\
\hline Callithamnion corymbosum (Smith) Lyngye & $\mathrm{x}$ & & \\
\hline Centroceras clavulatum (C. Agardh) Montagne & $\mathrm{x}$ & & $\mathrm{x}$ \\
\hline Ceramium brasiliense A.B. Joly & $\mathrm{x}$ & & $\mathrm{x}$ \\
\hline Ceramium brevizonatum var. caraibicum Petersen \& Børgesen & $\mathrm{x}$ & & $\mathrm{x}$ \\
\hline
\end{tabular}


Appendix 1. Cont.

\begin{tabular}{|c|c|c|c|}
\hline Taxa & $\begin{array}{l}\text { Amado Filho et al. } \\
\text { (2006) }\end{array}$ & $\begin{array}{l}\text { Coto and Pupo } \\
\text { (2009) }\end{array}$ & Present study \\
\hline Ceramium clarionense Setchell \& N. L. Gardner & $\mathrm{x}$ & & \\
\hline Ceramium codii (Richards) Mazoyer & $\mathrm{x}$ & & \\
\hline Ceramium comptum Bøergesen & $\mathrm{x}$ & & $\mathrm{x}$ \\
\hline Ceramium c.f. dawsonii & $\mathrm{x}$ & & \\
\hline Ceramium deslongchampsii Chauvin ex Duby & $\mathrm{x}$ & & \\
\hline Ceramium leutzelburgii Schmidt & $\mathrm{x}$ & & \\
\hline Ceramium sp ++ & $\mathrm{x}$ & & $\mathrm{x}$ \\
\hline Ceramium vagans P. C. Silva & $\mathrm{x}$ & & \\
\hline Chondria atropurpurea Harvey & $\mathrm{x}$ & & \\
\hline Chondria dangeardii E.Y. Dawson ** & & & $\mathrm{x}$ \\
\hline Chondria leptacremon (Melvill ex G. Murray) De Toni ** & & & $\mathrm{x}$ \\
\hline Chondria platyramea (A.B. Joly \& Ugadim) & $\mathrm{x}$ & & $\mathrm{x}$ \\
\hline Crouania attenuata (C. Agardh) J.Agardh & $\mathrm{x}$ & & \\
\hline Cryptopleura ramosa (Hudson) Kylin ex Newton & $\mathrm{x}$ & & \\
\hline Dasya rigidula (Kützing) Ardissone & $\mathrm{x}$ & & $\mathrm{x}$ \\
\hline \multicolumn{4}{|l|}{ Diplothamnion tetrastichum A.B. Joly \& Yamaguishi } \\
\hline Gayliella transversalis (F.S.Collins \& Hervey) T.O.Cho \& Fredericq & $\mathrm{x}$ & & \\
\hline Gayliella sp. 1 & & & $\mathrm{x}$ \\
\hline Gayliella sp. 2 & & & $\mathrm{x}$ \\
\hline Griffithsia schousboei var. anastomosans E.C. Oliveira & $\mathrm{x}$ & & $\mathrm{x}$ \\
\hline Griffithsia schousboei var. schousboei Montagne & $\mathrm{x}$ & & \\
\hline Haraldia tenuis E. C. Oliveira $* *$ & & & $\mathrm{x}$ \\
\hline Herposiphonia bipinnata M.A. Howe ** & & & $\mathrm{x}$ \\
\hline Herposiphonia secunda (C. Agardh) Ambronn & $\mathrm{x}$ & & $\mathrm{x}$ \\
\hline Herposiphonia tenella (C. Agardh) Ambronn * & & & $\mathrm{x}$ \\
\hline Heterosiphonia crassipes (Harvey) Falkenberg & $\mathrm{x}$ & & \\
\hline Heterosiphonia crispella (C. Agardh) M. J. Wynne & $\mathrm{x}$ & & $\mathrm{x}$ \\
\hline Heterosiphonia gibbesii (Harvey) Falkenberg & $\mathrm{x}$ & & \\
\hline Hypoglossum anomalum M. J. Wynne \& D.L. Ballantine & & & $\mathrm{x}$ \\
\hline Hypoglossum hypoglossoides (Stackhouse) F.S. Collins \& Hervey & & & $\mathrm{x}$ \\
\hline Laurencia c.f. caraibica & & & $\mathrm{x}$ \\
\hline Laurencia dendroidea $\mathrm{J}$. Agardh & & & $\mathrm{x}$ \\
\hline Laurencia marilzae Gil-Rodríguez, Senties et M.T. Fujii & & & $\mathrm{x}$ \\
\hline Laurencia oliveirana Yoneshigue & $\mathrm{x}$ & & \\
\hline Myriogramme prostrata (Dawson, Neushul \& Wildman) Wynne & $\mathrm{x}$ & & \\
\hline Neosiphonia ferulaceae (Suhr ex J. Agardh) Guimarães \& Fujii & $\mathrm{x}$ & & \\
\hline Neosiphonia gorgoniae (Harvey) S.M. Guimarães \& M.T. Fujii & $\mathrm{x}$ & & $\mathrm{x}$ \\
\hline Neosiphonia sphaerocarpa (Børgesen) M.S. Kim \& I.K. Lee* * & & & $\mathrm{x}$ \\
\hline Neosiphonia tongatensis (Harveyex Kützing) Kim \& Lee & $\mathrm{x}$ & & \\
\hline $\begin{array}{l}\text { Osmundea lata (M.A. Howe \& W.R. Taylor) Y. Yoneshigue-Valentin, } \\
\text { M.T. Fujii, \& C.F. Gurgel }\end{array}$ & $\mathrm{x}$ & & \\
\hline Osmundea sp. + & $\mathrm{x}$ & & $\mathrm{x}$ \\
\hline Polysiphonia decussata Hollenberg * & & & $\mathrm{x}$ \\
\hline Polysiphonia stricta (Dillwyn) Greville & $\mathrm{x}$ & & \\
\hline Polysiphonia scopulorum Harvey & $\mathrm{x}$ & & \\
\hline Polysiphonia subtilissima Montagne & $\mathrm{x}$ & & $\mathrm{x}$ \\
\hline \multicolumn{4}{|l|}{ Pterosiphonia parasitica (Hudson) Falkenberg } \\
\hline Pterosiphonia pennata (C. Agardh) Falkenberg & $\mathrm{x}$ & & \\
\hline Ptilothamnion speluncarum (Collins \& Hervey) Ballantine \& Wynne & $\mathrm{x}$ & & \\
\hline Spermothamnion nonatoi Joly & $\mathrm{x}$ & & \\
\hline Spyridia clavata Kützing & $\mathrm{x}$ & & $\mathrm{x}$ \\
\hline Spyridia hipnoides (Bory de Saint-Vincent) Papenfuss & $\mathrm{x}$ & & $\mathrm{x}$ \\
\hline Spyridia filamentosa (Wulfen) Harvey & $\mathrm{x}$ & & \\
\hline Wrangelia argus (Montagne) Montagne $*$ & & & $\mathrm{x}$ \\
\hline \multicolumn{4}{|l|}{ COLACONEMATALES } \\
\hline Colaconema hallandicum (Kylin) Afonso-Carillo, Sanson, Sangil \& & $\mathrm{x}$ & & \\
\hline \multirow{2}{*}{\multicolumn{4}{|c|}{ Diaz-Villa }} \\
\hline & & & \\
\hline Amphiroa anastomosans Weber-van Bosse & $\mathrm{x}$ & & $\mathrm{x}$ \\
\hline Amphiroa beauvoisii J. V. Lamouroux & $\mathrm{x}$ & & $\mathrm{x}$ \\
\hline Amphiroa rígida J.V. Lamouroux * & & & $\mathrm{x}$ \\
\hline Arthrocardia corymbosa (Lamarck) Decaisne **** & & & $\mathrm{x}$ \\
\hline Arthrocardia variabilis (Harvey) Weber-van Bosse * & & & $\mathrm{x}$ \\
\hline Corallina officinalis Linnaeus * & & & $\mathrm{x}$ \\
\hline Jania adhaerens J.V. Lamouroux & $\mathrm{x}$ & & $\mathrm{x}$ \\
\hline Jania capillacea Harvey* & & & $\mathrm{x}$ \\
\hline
\end{tabular}


Appendix 1. Cont.

\begin{tabular}{|c|c|c|c|}
\hline Taxa & $\begin{array}{c}\text { Amado Filho et al. } \\
\text { (2006) }\end{array}$ & $\begin{array}{c}\text { Coto and Pupo } \\
(2009)\end{array}$ & Present study \\
\hline Jania crassa J.V. Lamouroux & $\mathrm{x}$ & & $\mathrm{x}$ \\
\hline Jania cubensis Montagne ex Kützing & $\mathrm{x}$ & & \\
\hline Jania sagittata (J.V.Lamouroux) Blainville * & & & $\mathrm{x}$ \\
\hline Jania subulata (Ellis \& Solander) Sonder * & & & $\mathrm{x}$ \\
\hline Jania ungulata (Yendo) Yendo & $\mathrm{x}$ & & \\
\hline Lithophyllum stictaeforme (J.E. Areschoug) Hauck & $\mathrm{x}$ & & $\mathrm{x}$ \\
\hline Phymatolithon c.f. calcareum (Pallas) W.H. Adey \& D.L. McKibbin & & & $\mathrm{x}$ \\
\hline Pneophyllum fragile Kützing * & & & $\mathrm{x}$ \\
\hline \multicolumn{4}{|l|}{ ERYTHROPELTIDALES } \\
\hline Erythrotrichia carnea (Dillwyn) J. Agardh & $\mathrm{x}$ & & \\
\hline Erythrotrichia porphyroides Gardner & $\mathrm{x}$ & & \\
\hline Sahlingia subintegra (Rosenvinge) Kornmann & $\mathrm{x}$ & & \\
\hline \multicolumn{4}{|l|}{ GELIDIALES } \\
\hline Gelidium americanum (W. R. Taylor) Santelices ** & & & $\mathrm{x}$ \\
\hline Gelidium crinale (Turner) Gailon & $\mathrm{x}$ & & \\
\hline Gelidium microdonticum W.R.Taylor & & & $\mathrm{x}$ \\
\hline Gelidium sp. 1 & & & $\mathrm{x}$ \\
\hline Gelidium torulosum Kützing ** & & & $\mathrm{x}$ \\
\hline Parviphycus trinitatensis (W.R.Taylor) M.J.Wynne & $\mathrm{x}$ & & \\
\hline Pterocladiella caerulescens (Kützing) Santelices \& Hommersand & $\mathrm{x}$ & & $\mathrm{x}$ \\
\hline Pterocladiella capillaceae (S.G. Gmelin) Santelices \& Hommersand & $\mathrm{x}$ & & $\mathrm{x}$ \\
\hline \multicolumn{4}{|l|}{ GIGARTINALES } \\
\hline Chondracanthus acicularis (Roth) Fredericq & $\mathrm{x}$ & & $\mathrm{x}$ \\
\hline Chondracanthus saundersii C.W. Schneider \& C.E. Lane *** & & & $\mathrm{x}$ \\
\hline Chondracanthus teedei (Mertens ex Roth) Fredericq & $\mathrm{x}$ & & \\
\hline Craspedocarpus jolyi (Oliveira) Schneider & $\mathrm{x}$ & & \\
\hline Hypnea musciformis (Wulfen) J.V. Lamouroux & $\mathrm{x}$ & & $\mathrm{x}$ \\
\hline Hypnea spinella (C. Agardh) Kützing & $\mathrm{x}$ & & $\mathrm{x}$ \\
\hline Hypnea valentiae (Turner) Montagne & $\mathrm{x}$ & & \\
\hline Hypnea volubilis Searles in Schneider \& Searles & $\mathrm{x}$ & & $\mathrm{x}$ \\
\hline Solieria filiformis (Kützing) Gabrielson & $\mathrm{x}$ & & \\
\hline Wurdemania miniata (Duby) Feldmann \& Hamel & $\mathrm{x}$ & & \\
\hline \multicolumn{4}{|l|}{ GRACILARIALES } \\
\hline Gracilaria sp. & $\mathrm{x}$ & & \\
\hline \multicolumn{4}{|l|}{ HALYMENIALES } \\
\hline Cryptonemia delicatula Joly \& Cordeiro & $\mathrm{x}$ & & $\mathrm{x}$ \\
\hline Halymenia floridana J. Agardh & $\mathrm{x}$ & & $\mathrm{x}$ \\
\hline \multicolumn{4}{|l|}{ PEYSSONNELIALES } \\
\hline \multicolumn{4}{|l|}{ Peyssonnelia boudouresquei Yoneshigue } \\
\hline Peyssonnelia inamoena Pilger * & & & $\mathrm{x}$ \\
\hline Sonderophycus capensis (Montagne) M.J.Wynne * & & & $\mathrm{x}$ \\
\hline \multicolumn{4}{|l|}{ PLOCAMIALES } \\
\hline Plocamium brasiliense (Greville) M.A. Howe \& W.R. Taylor & $\mathrm{x}$ & & $\mathrm{x}$ \\
\hline \multicolumn{4}{|l|}{ RHODYMENIALES } \\
\hline Asteromenia peltata (W.R. Taylor) Huisman \& A.J.K. Millar ** & & & $\mathrm{x}$ \\
\hline Botryocladia bahamensis Ballantine \& Aponte *** & & & $\mathrm{x}$ \\
\hline Botryocladia pyriformis (Børgesen) Kylin & $\mathrm{x}$ & & \\
\hline Botryocladia wynnei Ballantine & & & $\mathrm{x}$ \\
\hline Ceratodictyon intricatum (C.Agardh) R.E.Norris & $\mathrm{x}$ & & $\mathrm{x}$ \\
\hline Ceratodictyon planicaule (W.R.Taylor) M.J.Wynne & $\mathrm{x}$ & & $\mathrm{x}$ \\
\hline Ceratodictyon scoparium (Montagne \& Millardet) R.E.Norris *** & & & $\mathrm{x}$ \\
\hline Ceratodictyon variabile (J.Agardh) R.E.Norris & $\mathrm{x}$ & & $\mathrm{x}$ \\
\hline Champia minuscula Joly \& Ugadim & $\mathrm{x}$ & & \\
\hline Champia parvula (C. Agardh) Harvey & $\mathrm{x}$ & & $\mathrm{x}$ \\
\hline Champia taironensis Bula-Meyer & $\mathrm{x}$ & & \\
\hline Champia vieillardii Kützing & $\mathrm{x}$ & & $\mathrm{x}$ \\
\hline Chrysymenia enteromorpha Harvey** & & & $\mathrm{x}$ \\
\hline Gastroclonium parvum (Hollenberg) C.F. Chang \& B.M. Xia & $\mathrm{x}$ & & \\
\hline Gloiocladia atlantica (Searles) R.E. Norris *** & & & $\mathrm{x}$ \\
\hline Gloiocladia iyoensis (Okamura) R.E. Norris & $\mathrm{x}$ & & $\mathrm{x}$ \\
\hline Lomentaria corallicola Børgesen & $\mathrm{x}$ & & $\mathrm{x}$ \\
\hline Leptofauchea brasiliensis Joly & $\mathrm{x}$ & & \\
\hline Rhodymenia delicatula Dangeard & $\mathrm{x}$ & & \\
\hline Rhodymenia pseudopalmata (J.V. Lamouroux) P.C. Silva & $\mathrm{x}$ & & $\mathrm{x}$ \\
\hline Sebdenia flabellata (J. Agardh) P.G. Parkinson * & & & $\mathrm{x}$ \\
\hline Stylonema alsidii (Zanardini) Drew & $\mathrm{x}$ & & \\
\hline $\begin{array}{l}\text { New records for: } \\
\text { * LSMSP; } \\
\text { ** São Paulo sate; } \\
\text { *** Brazil; } \\
\text { **** Ocidental Atlantic Ocean; } \\
\text { ***** South Atlantic Ocean. } \\
\text { + new species. } \\
\text { ++ probably a new genus. }\end{array}$ & & & \\
\hline
\end{tabular}

